\title{
記述長に基づく適応的 Ripple Down Rules法 Adaptive Ripple Down Rules Method based on Description Length
}

\author{
吉田 哲也
Tetsuya Yoshida \\ 大阪大学産業科学研究所 \\ The Institute of Scientific and Industrial Research, Osaka University. \\ yoshida@ar.sanken.osaka-u.ac.jp \\ $\underset{\text { Takuya Wada }}{\text { 和田 }}$ \\ (同上) \\ wada@ar.sanken.osaka-u.ac.jp \\ 元田 浩 \\ (同上) \\ motoda@ar.sanken.osaka-u.ac.jp \\ 熟尾 隆 \\ (同上) \\ washio@ar.sanken.osaka-u.ac.jp
}

keywords: ripple down rules method, minimum description length principle, knowledge deletion, pruning

\section{Summary}

A knowledge acquisition method Ripple Down Rules (RDR) can directly acquire and encode knowledge from human experts. It is an incremental acquisition method and each new piece of knowledge is added as an exception to the existing knowledge base. Past researches on RDR method assume that the problem domain is stable. This is not the case in reality, especially when an environment changes. Things change over time. This paper proposes an adaptive Ripple Down Rules method based on the Minimum Description Length Principle aiming at knowledge acquisition in a dynamically changing environment. We consider the change in the correspondence between attribute-values and class labels as a typical change in the environment. When such a change occurs, some pieces of knowledge previously acquired become worthless, and the existence of such knowledge may hinder acquisition of new knowledge. In our approach knowledge deletion is carried out as well as knowledge acquisition so that useless knowledge is properly discarded to ensure efficient knowledge acquisition while maintaining the prediction accuracy for future data. Furthermore, pruning is incorporated into the incremental knowledge acquisition in RDR to improve the prediction accuracy of the constructed knowledge base. Experiments were conducted by simulating the change in the correspondence between attribute-values and class labels using the datasets in UCI repository. The results are encouraging.

\section{1.はじめに}

知識ベースシステムの開発の前提として人間の専門家 か持っている知識は正しくかつ不変であり, 時間とコスト を費やしても専門家から知識を獲得することは非常に価 值があると考えられてきた .しかし，インターネットに代 表される通信ネットワークの進展によって大量のデータ を即座に入手することが可能になるに伴い，常に最新の 知識を保持するためには頻繁な知識の更新が必要となり 得る [Morik 93, Wrobel 94] . 弚のような状況下で実用的 な知識ベースシステムを構筑する枠組みとして, Ripple Down Rules 法 [Compton 89]（以下 RDR 法と呼ぶ）と 呼ばれる人間の専門家からの知識獲得を目的とした手法 が有望と我々は考えている．RDR 法では知識獲得を既 存の知識の逐次的な洗練と捉え，システムが事例を誤推 論するたびに，今まで正しく判断を下してきた知識の価 值を下げることなく新しい知識を既存の知識の例外知識 として追加する . 知識獲得は専門家とインタラクティブ
に行われ，知識獲得段階とシステム保守段階の間に明確 な境界はない，

従来の RDR 法は逐次的に例外知識を追加することで 知識ベースを更新するが, 問題領域の環境は静的で事例 の発生源となる母集団の性質は不変であることを仮定し， 知識べースのサイズが大きくなっても例外知識を追加し 続け，遭遇した事例を全て正しく推論できる知識ベース を構筑する．しかし, 技術革新の激しい今日, 知識の有 効性は時間とともに変化し，逐次的に知識べ一スを構築 する過程で以前正しいと判断され追加された知識が新し い状況では有効性*1を失うこともある. 有効性を失った 知識をも知識べースに保持し続けると，変化した環境下 で重要な知識の獲得を阻害する恐れがある．また，専門 家の知識も不変ではなく動的に変わりうるものであるた め, 一旦獲得した知識は将来にわたって有効性を持続す るという仮定は成立しにくい.このため, 環境が変化す

*1 本稿では未知データに対する予測精度から有効性を考える． 
る問題領域において継続的に知識ベースシステムの性能 を維持するためには，一旦獲得した知識であっても有効 性を失った時点で知識ベースから削除することが重要と なる .

我々は最小記述長原理 [Rissanen 78] (Minimum Description Length 原理:MDL 原理) を用いて専門家から の知識獲得とデータからの帰納学習手法を RDR 法に統 合化する手法を提案した [和田 $01 \mathrm{~b}]$. 本稿では環境変化 の一例として同じ属性-属性値の組合せを持つ事例に対す るクラスラベルの変化を考え, 知識獲得に加えて最小記 述長原理に基づく知識削除機能と知識汎化機能を導入し て RDR 法の知識ベースシステム (以下，RDR システム と呼ぶ）を構筑する手法を提案する . 提案する手法では 知識の追加, 削除, 汎化を統一的に扱うために正規化し た記述長を用いる．本稿では 15 種類のデータセットを用 い, 環境変化をシミュレートする人エデータからの逐次 的な知識べース構筑を行い, 提案手法か環境変化への適 応に対して有効であることを確認する。

2 章では Ripple Down Rules 法による知識獲得につい て説明し， 3 章では提案する知識削除および知識汎化機 能のアルゴリズムについて説明する .4 章では提案手法 を実験的に評価する．最後に 5 章で結論を述べる．

\section{Ripple Down Rules 法による 知識獲得}

\section{2・1 Ripple Down Rules 法}

RDR 法は知識エンジニアによる分析やインタビュー などを必要とせず, 専門家が直接知識ベースシステムを 開発することによって, 知識獲得ボトルネックを解消し ようとする知識獲得技術である．RDR システムでは，あ る事例か誤って推論された場合，知識獲得 (保守) 段階 において，なぜ产の事例に対する推論が知識ベースに蓄 積されている過去に正しく推論された事例に対する推論 と異なるのかを専門家に判断させる必要がある．

RDR システムは図 1.(a) に示すように二分木として表 現される . 各ノードはルール (If-Then ルール) と产の ノード自身が追加される原因となった代表事例 (cornerstone case) を記憶し，二つの枝 (YES 枝と NO 枝) を 持つ. 事例に対する RDR 法の推論は根ノードから始ま り (RDR 法か推論する事例を推論事例と呼ぶ），产の事 例がノードの持つルールの条件部を満足すればYES 枝の ノードに，光うでなければ $\mathrm{NO}$ 枝のノードに推論を移行 し，これ以上進むべきノードが存在しなくなるまでこの 過程を繰り返す . あるノードの YES 枝の下のノードは， 光のノードの条件部が満足された場合に対する例外知識 を表現するため，弚のノードに対する例外ノードと呼ぶ . ノードの遷移が停止したノードを end node と呼び，根 ノードから end node までの経路を推論パスと呼ぶ. 事 例に対する RDR 法の結論は，推論パス上で一番最後に 条件部が満足されたノード (last satisfied node, 以下で
は LSN と呼ぶ）の持つ If-Then ルールの帰結部となる . 根ノードのルールの条件部はどのような事例に対しても 成り立ち，光の帰結部は事例に対する結論が RDR シス テムから導かれなかった際の暗黙の結論（デフォルト知 識) を表すデフォルトクラスか設定される .デフォルト クラスはシステム構築前に設定される .

事例に対する推論結果が尃門家の判断する結果と異な る場合，専門家から知識（新しいIf-Then ルール）を獲 得し，既存の二分木に追加する . 図 1.(b) にRDR 法に おける知識獲得の樣子を示す . RDR システムに追加する ためのルールの条件部を決めるために二つの事例の差異 (difference list, 以下では D-List と呼ぶ) を専門家に提 示し, 追加ノードの If-Then ルールの条件部となる要素 を選んで貪う .二つの事例とはRDR による推論によっ て誤判断された推論事例と，弚れに対する誤った結論を 出したノードの持つ代表事例である . D-List は代表事例 が否定し，推論事例が肯定する条件を要素とする集合で あり，二つの事例を区別する条件集合の選択に使用する． 誤判断された事例に対する正しい結論を正当化するため に専門家がD-List から選んだ条件の連言を条件部，正し い結論を帰結部とする If-Then ルールを，追加するノー ドが保持するルールとし, 誤推論された推論事例をこの ノードの代表事例とする . 新しいノードの追加位置は, LSN が end node であれば end nodeの YES 枝の下，光 うでなければ end nodeの NO 枝の下とする .

RDR 法では知識獲得を既存の知識の逐次的な゙洗練と捉 え，知識ベースを再編することなく，新しいノードを最後 に条件部が満足されたルールを持つノードの例外ノード として代表事例とともに追加するだけであり，知識は決 して移動したり変更されることがない．このため, RDR 法は知識獲得段階で各知識が追加されたときの文脈と同 じ文脈で光れ光れの知識が使われることを保証する．

\section{$2 \cdot 2$ 最小記述長原理に基づく RDR 法}

RDR 法は人間の専門家から知識を獲得する手法であ るため専門家の判断力に強く依存する. しかし専門家と いえども時には間違いも犯すため，専門家からの知識獲 得だけに頼るのではなく，データからの帰納学習手法を 利用して知識ベースシステムを構築することか望ましい． 我々は MDL 原理を用いてデータからの帰納学習手法を RDR 法に統合化する手法を提案し，关の有効性を確認 した [和田 01b]. MDL 原理は与えられた観測データを もとに, 複数の選択肢の中から最良と思われる仮説を選 引際の一般的な選択規範であり，データを説明するのに 最もシンプルな仮説を選択すべきとの規範である．仮説 の複雑さは Rissanen [Rissanen 78] が提案した“記述長 (Description Length: DL) ”として求められる.

二分木で表現される RDR 法の知識モデルは, データ の分割の仕方と，乥れに基づいて分割されたデータの部 分集合に対する代表クラスから構成されていると見なす 


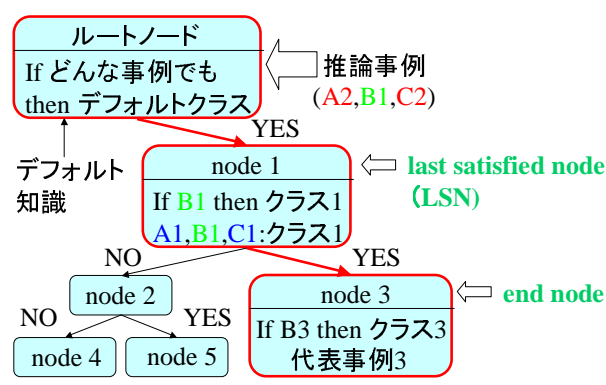

推論パス:

ルートノード $\rightarrow$ node $1 \rightarrow$ node 3

RDR法の推論結果 : クラス 1
専門家の推論結果: クラス 2

(a) RDR法の知識ベースと推論

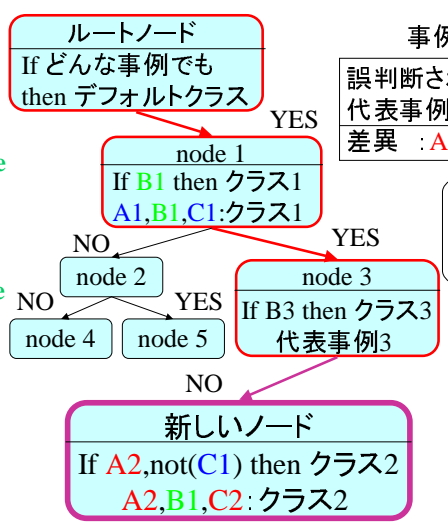

事例の差異の導出

判断された事例: A2,B1,C2

表事例 : A1,B1,C1

異 : $\mathrm{A} 2, \operatorname{not}(\mathrm{A} 1), \mathrm{C} 2, \operatorname{not}(\mathrm{C} 1)$

推論事例はA2と

$\operatorname{not}(\mathrm{C} 1)$ であるか

らクラス2である.

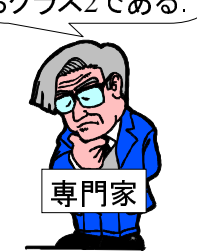

(b) RDR法の知識獲得

図 $1 \mathrm{RDR}$ の知識構造と知識獲得アルゴリズム

表 1 データの例

\begin{tabular}{|c|ccc|c|}
\hline No. & 属性 Swim & 属性 Breath & 属性 Legs & クラス \\
\hline 1 & can & lung & 2 legs & Dog \\
2 & can & lung & 4 legs & Penguin \\
3 & can & skin & 2 legs & Monkey \\
4 & can & skin & 4 legs & Dog \\
5 & can_not & lung & 2 legs & Cat \\
6 & can_not & lung & 4 legs & Cat \\
7 & can_not & gill & 2 legs & Dog \\
8 & can_not & gill & 4 legs & Monkey \\
9 & can_not & skin & 2 legs & Penguin \\
10 & can_not & skin & 4legs & Penguin \\
\hline
\end{tabular}

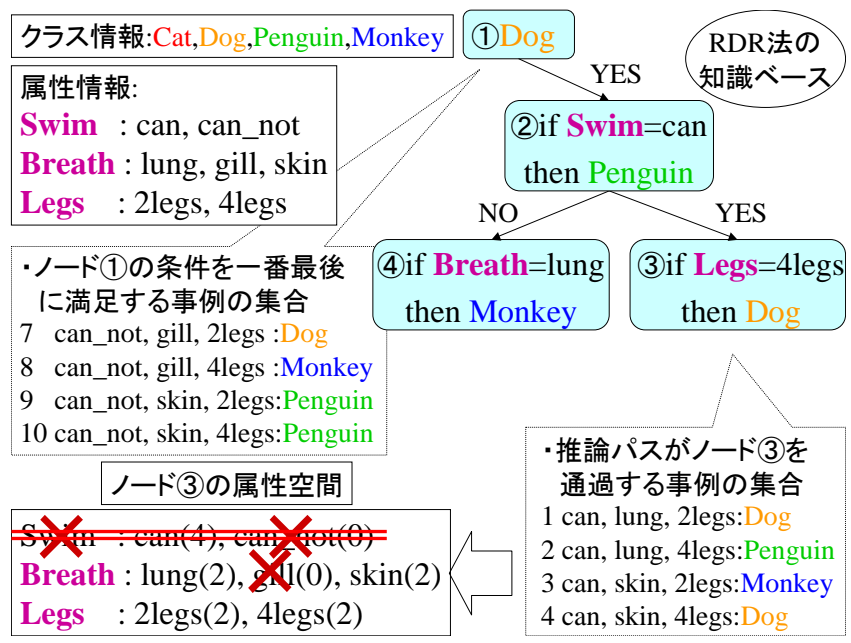

図 $2 \mathrm{DL}$ の計算を例証するための二分木の例

ことができる，従って，ある適切な符号化方法の下で， $\mathrm{RDR}$ システムの DL は 1 ) 知識モデル (RDR 法の二分 木) に対する DL と 2) 兴の知識モデルで誤推論される 事例（これを誤推論事例と呼ぶ）の真のクラス情報に対 するDL の和として計算される.我々が提案した符号化 方法の詳細は文献 [和田 01b, Wada 01a] を参照された い．1）の二分木の符号化では各ノードに対して枝情報と If-Then ルール情報を符号化する必要があり，推論過程で 各ノードを通過する事例の集合から表現すべき情報（こ れを属性空間と呼ぶ）を考慮して符号化を行う.このた め，従来の RDR 法と異なり，MDL 原理に基づく RDR
法では図 2 に示すように各ノードは代表事例以外にも光 のノードをLSN とする事例集合も保持する .2) の誤推 論事例のクラス情報の符号化では, 各ノードを LSN と する事例のうち誤推論事例となるもののクラスラベルを 光れ光れ符号化する。

MDL 原理に従えば全体の DL が最も小さくなるモデ ルを選択すべきであるため，RDR システム全体の DL が 最小となる二分木を選択すればよい，ただし，符号化方 法のほとんどは誤推論事例のクラス情報に比べて知識モ デルの DL を多く見積もりすぎる傾向があることが知ら れている [Quinlan 93] .このため, RDR システム全体 の DL を

$$
\begin{aligned}
\text { 全体の } \mathrm{DL}= & (\text { 知識モデルの } D L) \times w \\
& +(\text { 誤推論事例のクラス情報の } D L)
\end{aligned}
$$

と計算し , 著者らの実験に基づく経験的な値として $w=$ 0.3 を採用している。

MDL 原理に基づく RDR 法では下記のように知識獲 得を行う.

専門家からの知識獲得 従来の RDR 法と同樣, D-List から専門家に 1 個以上の要素を選択して貪い, 選択さ れた条件集合を新しく追加するノードでの If-Then ルールの条件部とする .

データからの知識獲得 D-List の部分集合のうち, 新 しいノードの条件とした場合に RDR システム全体 の DL が最小になる部分集合を欲張り探索する . 探 索の詳細は [和田 01b] を参照されたい .この方法に より，専門家に頼ることなくデータのみから帰納的 に知識ベースを構築することが可能となる．

データと専門家からの知識獲得＼cjkstart専門家の知識も積極 的に利用するために, 専門家が D-List から選択し た条件集合を探索の開始点として記述長が更に小さ くなる条件を欲張り探索する.MDL 原理の観点か ら，専門家が選んだ条件よりもさらに良い条件を見 つける可能性がある . 


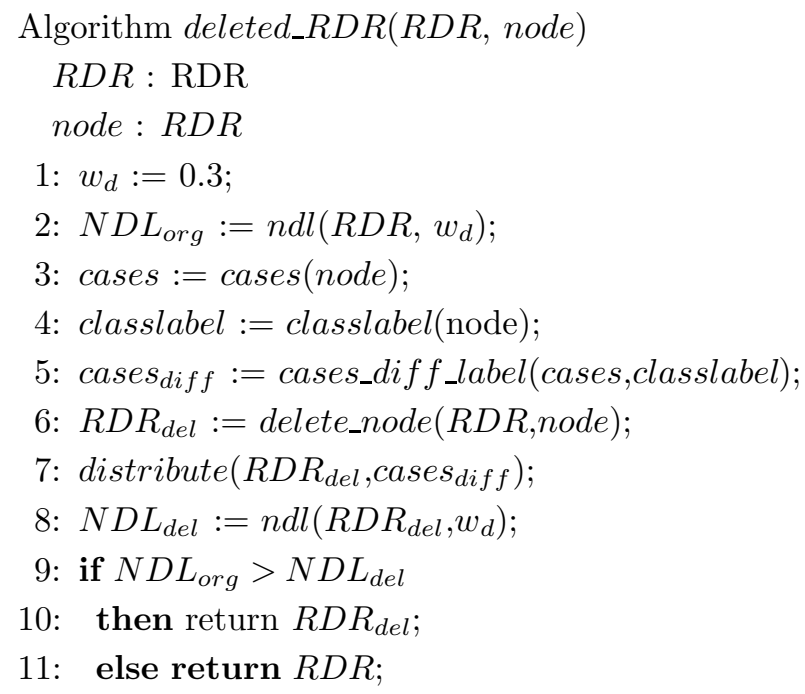

$n d l(R D R, w): R D R$ システムの正規化した記述長（式 (1) で重み $w$ で計算)

cases(node): node の保持事例集合

classlabel(node): node が保持する If-Then ルールの帰 結部のクラスラベル

cases_diff_label(cases,label): クラスラベルがlabel 以 外の事例集合

distribute(RDR,cases): 事例集合 cases $R D R$ シス テムで推論し, LSN となるノードに分配

図 3 ノード削除アルゴリズム

\section{3. 適応的 Ripple Down Rules 法}

知識削除機能と知識汎化機能を実現する手法として， 二分木で表現される RDR システムのノード削除と枝刚 りを提案する .ノード削除や枝刈りは推論事例の誤判断 を契機に実施する．後述するようにノード削除の方がよ り積極的に環境変化に適応する手法であるため，併用す る場合には，まずノード削除を行い，次に枝刈りを行う． 以下では, RDR システムが入力として受け取る個々の 事例を単に事例と呼び，RDR の推論結果が間違ってい た事例を特に誤推論事例と呼ぶ．また，各ノードが保持 している個々の事例 (光のノードをLSN とする事例) を 保持事例と呼び，保持事例の集合を保持事例集合と呼ぶ．

\section{$3 \cdot 1$ ノド 削 除}

環境変化した母集団から抽出した事例を RDR システ ムにより推論した場合, 光の事例と同じ属性 - 属性値の 組合せを持つ事例を過去に正しく推論した知識を保持し ていても, 事例に対するクラスラベルが変化しているた めに RDR システムの推論結果は誤推論となってしまう . この場合はシステムが保持する代表事例と推論事例との 差がないため D-List は空集合になり，従来の RDR 法で はノードの追加による知識獲得が行えない . また , D-List が空集合でない場合でも，専門家が重要と考える条件が
D-List に含まれなければ，D-List から選択された条件を 用いた If-Then ルールを知識とするノードを追加するこ とは意味がない .

環境変化への単純な対応策としては, 変化を検知する 毎に構築した RDR システムを破棄し，新たな環境の下 でRDR システムを再構築する事が考えられる．しかし， 変化を検知する毎にシステムを再構築することは逐次的 な例外知識の追加という RDR 法のアプローチに光ぐわ ない．また知識の再利用という観点から，無効となった 知識のみを削除し，新たな環境下でも有効なものを保持 し続けるという枠組みの方か望ましい，乥こで，RDR シ ステムでは各ノードが推論知識を表現する If-Then ルー ルを保持しているため，無効となった知識を保持してい るノード，つまり RDR システムが誤推論した事例に対 するLSN を削除することが考えられる. しかし RDR 法 は既存の知識に矛盾する事例を契機として新たな例外知 識を獲得する手法であるため，RDR システムが誤推論 するたびにノードを削除すると知識獲得自体ができなく なってしまう。

本稿ではシステムの推論結果が誤っているたびに例外 知識を追加するという元来の RDR 法を MDL 原理に基 づいて以下のように拡張する :

（1）[和田 01b] の方法と同樣に，RDR システムが事例 を誤推論した場合でも，誤推論を修正するためのノー ドの追加が全体の記述長を減少させなければノード を追加しない .

（2）更に,記述長が減少するならば，誤推論事例に対 する LSN となるノードを RDR システムから削除 し，二分木を再編する．

この (2) にあたる，RDR システムからのノード削除ア ルゴリズムを図 3 に示す .

$2 \cdot 2$ 節で述べた MDL 原理に基づく RDR 法では，各 ノードは If-Then ルールとともにぞのノードを LSN と する事例の集合を保持する.誤推論事例に対する LSN を RDR システムから削除する際, 図 4 に示す関数 delete_node により二分木からノードを削除して木構造を再編すると ともに，弚のノードの保持事例集合の中で If-Then ルー ルの帰結部と同じクラスラベルを持つ事例もあわせて削 除する.これは, 帰結部と同じクラスラベルを持つ保持 事例だけが兴の If-Then ルールの有効性を支持している と考えるからである.削除されたノードが保持する残り の事例，すなわち If-Then ルールの帰結部と異なるクラ スラベルを持つ事例は, 再編した RDR システムで再推 論して新たな LSN に分配する .

なお，RDR システムの記述長は事例数に対し単調に 増加するため, ノードの削除前後の記述長を単純に比較 しても意味がない .この点を補正するため，RDR シス テムが保持する事例に対して RDR システムの記述長を DL/DL' と正規化して比較する (以下，正規化した記述 長を NDL と呼ぶ）。ここで，DL'は二分木の情報を用 
関数 delete_node $(R D R$, node $)$

$1: R D R^{\prime}:=R D R \backslash \backslash$ copy $R D R$ into $R D R^{\prime}$

2:if has_child(node, YES)

3:then

4: parent $:=$ parent $($ node $)$;

5: if edgelabel $($ parent, node $)=\mathrm{YES}$

6: then

7: child(node, YES) を parent に YES 枝で接続;

8: node $^{\prime}:=\operatorname{child}($ parent, YES);

9: else

10: child(node, NO) を parent に NO 枝で接続;

11: node $^{\prime}:=\operatorname{child}($ parent, $\mathrm{NO})$;

12: repeat while (has_node $($ node', $\mathrm{NO})$ )

13: add_cond(node,node');

14: node $^{\prime}:=\operatorname{child}($ node', $\mathrm{NO})$;

15: add_cond(node,node');

16: if has_child(node, NO)

17: then child(node, NO) をnode'に NO 枝で接続;

\\node がYES 枝の子ノードを持たない場合

18:else if has_childe(node, NO)

19: then

20: parent $:=\operatorname{parent}($ node $)$;

21: if edgelabel(parent, node) $=\mathrm{YES}$

22: then child(node,NO) を parentにYES 枝で接続;

23: else child(node,NO) を parent にNO 枝で接続;

24:return $R D R^{\prime}$;

has_child(node, label): node はlabel で接続する子ノー ドを持つ

edgelabel $\left(\right.$ node $\left._{A}, \operatorname{node}_{B}\right): \operatorname{node}_{A}$ から $\operatorname{node}_{B}$ に接続す る枝のラベル

add_cond $\left(\right.$ node $_{A}$, node $\left._{B}\right):$ node $_{A}$ の If-Then ルールの条 件部を $\operatorname{node}_{B}$ の条件部に連言として追加

図 4 関数 delete_node: RDR システムから指定したノードを削除

いずに各保持事例の正しいクラス情報を符号化するのに 必要な記述長として根ノードの情報のみを用いた場合の 記述長を表す。

$\mathrm{RDR}$ システムからノードを削除する例を図 5 に示す． 図 5 で誤推論事例に対する LSN はノード 2 であり，光 の If-Then ルールの条件部を “cond.2” と表記する . ま ず，図 4 に示す関数 delete_node の 7 行目でノード 2 に YES 枝で接続する子ノード 4 をノード 2 の親ノードであ るノード 1 に YES 枝で接続してノード 2 を削除する. 光 の際, ノード 4 と, ノード 4 の $\mathrm{NO}$ 枝に繋がるノードを根 ノードとする部分木に含まれるノードの If-Then ルール は , ノード 2 のIf-Then ルールの条件部 “cond.2”が満た される場合に対する例外知識である．これらのノードが 保持する知識の整合性を保つために，関数 delete_node の 13 行目で削除したノード 2 での条件部 “cond.2”を

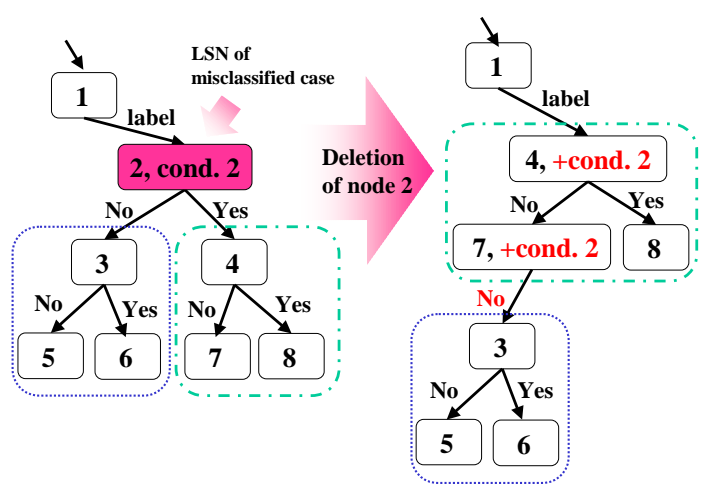

図 5 ノード削除の例

ノード 4 の条件部に追加する (図 5 で “+cond.2” は条 件部を追加したことを表す) . 同樣に , ノード 4 から $\mathrm{NO}$ 枝のみを辿って到達できる全てのノード（図 5 ではノー ド 7 のみ) の If-Then ルールに条件部 “cond.2”を追加す る．次に，ノード 2 に NO 枝で接続していた，ノード 3 を根ノードとする部分木を, 関数 delete_node の 17 行目 でノード 4 を根ノードとする部分木で $\mathrm{NO}$ 枝を辿った葉 ノード (この場合はノード 7) に NO 枝で接続する .ノー ド削除アルゴリズムはノード削除前後の NDL を比較し， 再編後の RDR システムの NDL が再編前の NDL より 減少していれば, 再編後の RDR システムを返す．

上記の操作において，削除したノード 2 での条件 “cond.2” を追加することで再編後の二分木に含まれるノードが保 持する知識の整合性が維持されていることがわかる．た とえば, ノード 2 を削除する前では, ノード $3,5,6$ の各 保持事例に対する RDR による推論はノード 2 の条件部 “cond.2” か満たされないためノード 3 を根とする部分木 で行われる . 再編後の二分木においても , ノード 4,7 の 条件部に条件 “cond.2”を追加したためにノード 4,7 の 条件部が満たされず，ノード $3,5,6$ の各保持事例に対す る RDR による推論はノード 3 を根とする同じ部分木で 行われる . ノード 2 の削除前後で同じ推論結果が得られ るため, RDR システムが保持する知識の整合性を維持 したノード削除を実現できる .

\section{$3 \cdot 2$ デフォルトクラス}

デフォルトクラスが異なれば同じ事例集合に対しても 性能の異なる RDR システムが構築される [和田 00] . 2 章で述べたように従来の RDR 法ではデフォルトクラス は固定されており，RDR システムが事例を誤推論するた びに新しいノードを追加していた . 他方 , 提案手法では 記述長が減少しなければノードは追加されず, 誤推論事 例は炎の LSN に保持される . また，各ノードの保持事例 集合はシステムが逐次的に受け取る事例に依存して変化 する . システムへの入力となる事例の性質が変化した場 合には, 弚の変化に追随して適切なデフォルトクラスを 設定できることが望ましい .このため, システムが受け 
取る事例に基づいて逐次的にデフォルトクラスを設定す る手法として , システム全体の記述長が最小化されるク ラスラベルをデフォルトクラスとするよう拡張した . 根 ノードは条件部がなく，枝を必ず 1 つ持つため，根ノー ドの保持事例集合において最頻なクラスをデフォルトク ラスとすると記述長が最小になる．逐次的に受け取る事 例を反映しデフォルトクラスを用いることにより，環境 か変化した場合に RDR システムから正しい推論結果を 得られやすくなる。

しかし , 根ノードの保持事例集合における最頻クラス をデフォルトクラスと設定することでシステムの正答率 は向上するものの , デフォルトクラスに対する推論は事 例の頻度に基づいおり，根ノードが LSN となる事例を 推論するための明示的な推論知識 (If-Then ルール) が システム内部に表現されているわけではない .このため， ある事例に対して根ノードがLSN となった場合には，推 論結果の正否に関わらず例外ノードを追加した場合と追 加しない場合の記述長を比較し, 記述長の小さい方を選 択することとした . 例外ノードが追加された場合には， 兴の事例を推論するための If-Then ルールか明示的な知 識としてシステムに追加されることになる . 本来 RDR システムの推論結果が正しい場合は D-List が定義でき ないが，この場合には根ノードの推論結果か間違ってい たと仮定してD-List を定義し， $2 \cdot 2$ 節で述べた手法で例 外ノードを追加した場合の条件部を探索する .ただし根 ノードは代表事例を持たないため，D-List に含まれる要 素は推論事例の属性値のみとなる .

事例に対する LSN が根ノードの場合に対するシステ ムの挙動を下記にまとめる .

(1) システムは根ノードの保持事例集合における最頻 クラスをデフォルトクラスとして推論する .

(2) 推論結果の正否にかかわらず, 兴の事例を推論す るための If-Then ルールを表現する例外ノードの追 加を試みる .MDL 原理に基づき , ノードを追加した 場合のほうが，追加しない場合よりもシステム全体 の記述長が小さいならば龹のノードを追加する .

(3) ノードが追加された場合には，ノード追加後の RDR システムの整合性を保つために根ノードの保 持事例集合をノード追加後の RDR システムで再推 論し，新しいLSN に分配する．この処理により，新 たに追加したノードが LSN となる事例が兴のノー ドの保持事例として移動される .

\section{$3 \cdot 3$ 枝刈りによる 知識汎化}

RDR システムを分類器と捉えると, 予測精度を向上 させるにはシステム構築に用いた訓練事例に対して特化 し過ぎない分類器を構筑することが重要である.バッチ 処理で分類器を構筑する機械学習法の一つである $\mathrm{C} 4.5$ では訓練事例に特化した分類器 (決定木) を枝刈りによ り汎化して予測精度の高い分類器を構筑することに倣い，

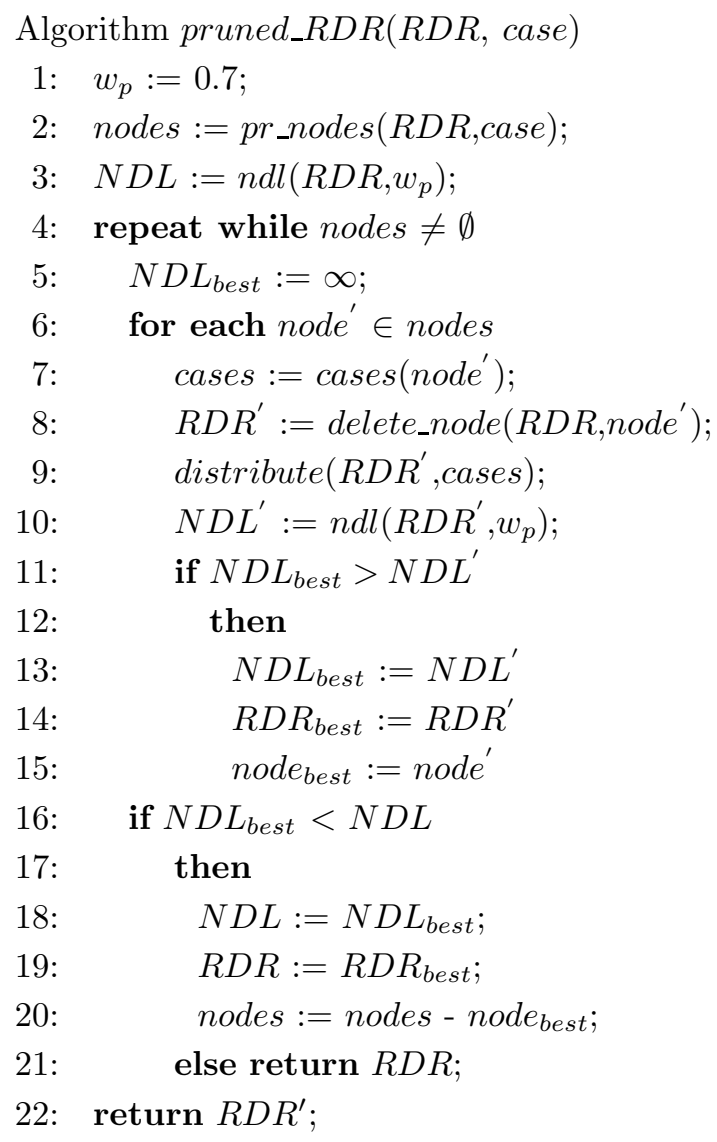

pr_nodes $(R D R$, case $): R D R$ により case を推論した際 の枝刈り対象ノードの集合

図 6 枝刚りアルゴリズム

逐次的な知識ベース構築手法である RDR 法に枝刈りに よる知識汎化機能を導入した . 一旦システムに追加した ノードを後に削除するという意味で $3 \cdot 1$ 節のノード削除 の一種とみなすことができる．ただし，枝刈りの目的は 予測精度の向上であるため, 属性-属性值の組み合わせと クラスラベルの対応が変化しない静的な環境においても 適用可能である.

提案するRDR 法での枝刈りアルゴリズムを図 6 に示 す. $3 \cdot 1$ 節のノード削除と同樣に正規化した記述長の最 小化という規範で枝刈りを行う．ノード削除との違いは 事例が削除されないことであり，枝刈りされたノードが 保持していた各事例は削除されることはなく，全て再編 後の RDR システムのノードに再分配される .このため， If-Then ルールとして表現される知識のみが RDR シス テムから削除されることになる . RDR システムが事例 を正しく分類した場合にはシステムが保持する知識は事 例と無矛盾であるため枝刈りを行わないが , $3 \cdot 2$ 節のよ うにデフォルトクラスを設定しているため根ノードでの 推論結果は事例とともに変化する可能性がある .このた め，現状では RDR システムにより事例を分類した際に， 1) 新しいノードを追加した場合，2) 事例に対する LSN か消除された場合，3) 事例に対する LSN が根ノードの 
場合，に枝刘りを行うこととしている。

二分木に含まれる全ノードを枝刚り候補とすることも 考えられるが，ノード数に比例して枝刈り処理に要する 計算時間が増加するため関数 pr_nodes により枝刈り候 補ノードを絞っている．現状では RDR システムにより 事例を分類した際の推論パス上のノードのうち, YES 枝 に子ノードを持たないノードを候補としている．理由は， 関数 delete_node により二分木を再編した際, 削除した ノードが YES 枝を持つと図 5 に示すように再編後の二 分木が $\mathrm{NO}$ 枝に偏りがちになるため，枝刈りによって二 分木が偏ることを防ぐためである .

なお，知識獲得やノード削除では式 (1) における重み $w$ を 0.3 としており，枝刈りでは予備実験の結果に基づ いて $w=0.7$ とした . 大きな重み $w(0.7>0.3)$ を用いて知 識モデル (二分木) のDL に対する影響を大きくして積 極的に枝刈りを行うことに対応する。

\section{4. 評 価 実 験}

環境変化に対する知識削除機能および枝刈り機能の有 効性を検証するため, California 大学 Irvine 校の機械学 習データセットライブラリ [Blake 98] のうち 15 データ セット (表 2 参照) を用いて評価実験を行った。環境変 化をシミュレートする人エデータを生成し，提案手法を 用いて構築した RDR システムの予測精度と NDL を評 価した。

\section{$4 \cdot 1$ 実 験 条 件}

[人エデータ] ある環境に対応する事例集合 $X_{\text {org }}$ に 対し，異なる環境に対応する事例集合 $X_{c h g}$ を以下 の操作で生成した . まず $X_{\text {org }}$ に含まれる全事例を クラスラベルに関して辞書順にソートし，次にソー 卜後の順序を保ったまま同じクラスラベルを持つ事 例を属性-属性值のペアに関して離散属性は辞書順 , 数值属性は昇順にソートした。最後に, $x \%$ 分の事 例でクラスラベルを変化させるために (全事例数 ： クラス数 $\div(100 \div x))$ の事例分だけクラスラベルを スライドさせ，事例集合 $X_{c h g}$ を生成した . $X_{c h g}$ は $X_{\text {org }}$ から $x \%$ の事例のクラスラベルか変化した環境 に対応する .

[訓練データと評価データ]＼cjkstart事例集合 $X$ を $75 \%$ の訓 練データ $\left(X^{\text {train }}\right)$ と $25 \%$ の評価データ $\left(X^{\text {test }}\right)$ に 分割した .ある環境を表す事例集合 $X$ の下での知識 獲得では， $X^{\text {train }}$ を集団として指定した事例数分 だけ復元抽出により $X^{\text {train }}$ から事例を無作為抽出 して逐次的に RDR システムを構筑した 。

[環境変化]抽出事例から逐次的にシステムを構筑す る過程て環境が二度变化する状況を想定し, 各データ セットごとに元の事例集合 $X_{\text {org }}$ から環境か湾化した 二つの事例集合 $\left(X_{c h g 1}, X_{c h g 2}\right)$ を生成し， $X_{c h g 2}$

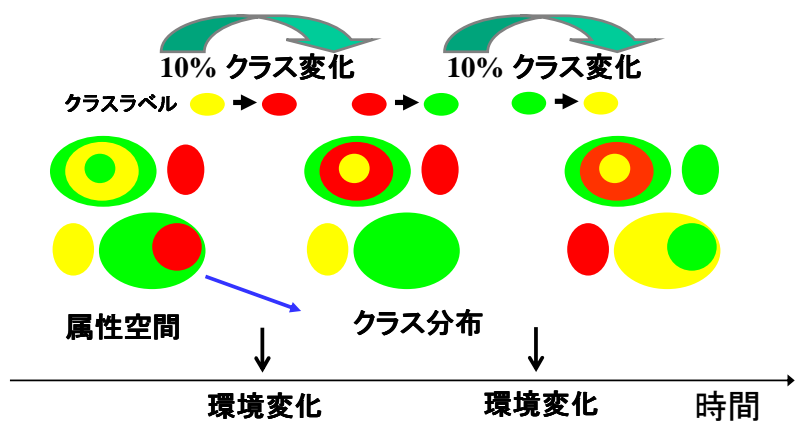

図 7 実験で使用した環境変化

$\rightarrow X_{c h g 1} \rightarrow X_{o r g}$ と変化した場合と $X_{o r g} \rightarrow X_{c h g 1}$ $\rightarrow X_{c h g 2}$ と変化した場合を評価した．環境変化の割 合は $X_{c h g 1}$ では $10 \%, X_{c h g 2}$ では $20 \%$ とした . 環 境 $X$ からの抽出事例数を $\left|X^{\text {train }}\right|$ の 3 倍とし，た とえば $X_{c h g 2}$ からの抽出事例数が $3\left|X_{c h g 2}^{\text {train }}\right|$ に達し た時点で事例集合を $X_{c h g 1}$ に変更した。実験で使用 した環境変化を図 7 に示す. 図 7 ではクラスラベル を濃淡で表示し，環境変化のたびにクラス分布にお ける部分集合に対応するクラスラベルが変化するこ とを示す．

[代替専門家]実験の再現性と性能評価の必要性から， 従来研究では計算機プログラムで構築した代替専門 家 (Simulated Expert: SE) [Compton 95] から 知識獲得を行い性能評価しているため, 本稿でも代 替専門家を用いて評価した．環境を反映する事例集 合が $X$ である際には $X^{\text {train }}$ に対して機械学習法 C4.5rules[Quinlan 93] を用いて導出した If-Then ルール集合を SE の知識源とした . SE が D-List か ら選択する条件は，RDR システムが誤推論した事 例を正しく分類する SE の If-Then ルール (これを 発火した If-Then ルールと呼ぶ）の条件部と D-List の共通部分とした . 共通部分が無い場合は SE の知 識 (If-Then ルール) を活用できないためデータから の知識獲得を行った .

環境が $X_{\alpha}$ から $X_{\beta}$ に変化した時点で, $\mathrm{SE}$ の知識 源である If-Then ルール集合を $X_{\alpha}^{\text {train }}$ に対するも

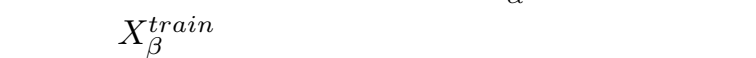
$\mathrm{SE}$ は非常に性能の高い専門家であり, 環境変化に合 わせて自身の知識を直ちに切替え可能であることを 意味する .なお C4.5rules で得られる If-Then ルー ルでは否定条件 (not) が表現されないため, SEが 否定条件も D-List から選択できるように属性値のバ イナリー化を行って SEの If-Then ルールに否定条 件が表現されるようにした .

[分類精度] 逐次的に構築した RDR システムのエラー 率を評価データに対して計測した。母集団が $X_{\alpha}^{\text {train }}$ である間は $X_{\alpha}^{\text {test }}$ を評価データとして,$X_{\beta}^{\text {train }}$ に変 化した後は $X_{\beta}^{\text {test }}$ を評価データとした。なお， RDR 
表 2 データセット概要

\begin{tabular}{|l|c|c|c||l|c|c|c|}
\hline データセット名 & 事例数 & クラス数 & 属性数 & データセット名 & 事例数 & クラス数 & 属性数 \\
\hline Car & 1728 & 4 & Nom. ${ }^{*} 6$ & PageBlocks & 5473 & 5 & Num. 10 \\
\hline Nursery & 12960 & 5 & Nom. 8 & PenDigits & 10992 & 10 & Num. 16 \\
\hline Mushrooms & 8124 & 2 & Nom. 22 & Yeast & 1484 & 10 & Num. 8 \\
\hline Krvkp & 3196 & 2 & Nom. 36 & PimaIndians & 768 & 2 & Num. 6 \\
\hline VotingRecord & 435 & 2 & Nom. 16 & GermanCredit & 1000 & 2 & Mix. $^{* * *} 13 / 7$ \\
\hline BreastCancer & 699 & 2 & Nom. 9 & Cmc & 1473 & 3 & Mix. $7 / 2$ \\
\hline Splice & 3190 & 3 & Nom. 60 & AnnThyroid & 7200 & 3 & Mix. $15 / 6$ \\
\hline Image & 2310 & 7 & Num. $^{* *} 19$ & & & & \\
\hline
\end{tabular}

* 離散值属性, ${ }^{* *}$ 連続值属性, ${ }^{* * *}$ 離散值属性と連続值属性が混在: 離散值属性の数/連続值属性の数

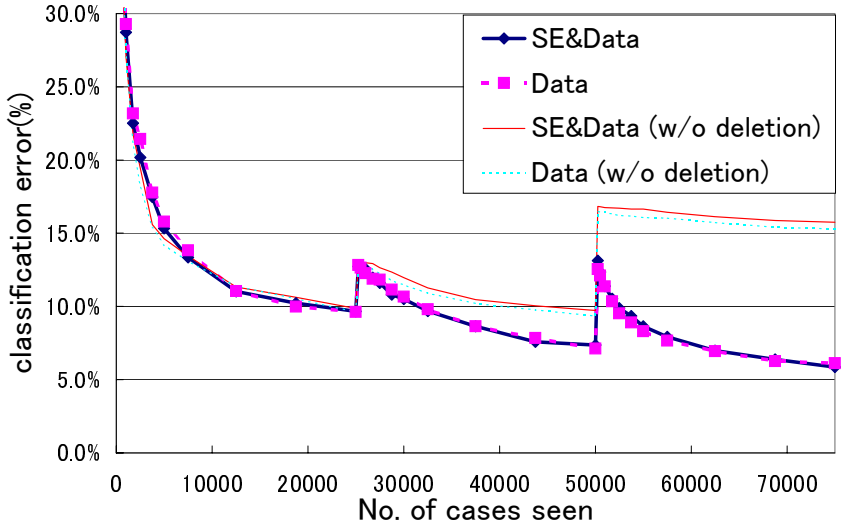

図 8 データセット “PenDigits” に対するエラー率の変化 (10 回 試行平均, $X_{c h g 2} \rightarrow X_{c h g 1} \rightarrow X_{\text {org }}$ )

法は逐次的な手法であるため，構築した RDR シス テムの性能は抽出した事例の順序に依存する .この ため, 各データセットに対して無作為抽出の順序を 変えた 10 回試行の平均をエラー率とした . また , 削 除機能，枝刈り機能を用いる場合と用いない場合の 予測精度を対応のある $\mathrm{t}$ 検定 (片側検定) を用いて 有意水準 $99 \%$ で検定した。

上記の実験条件は環境変化の一例にすぎないが, 本稿で は実験の再現性と一貫した精度評価のために上記の実験 条件を用いることとした . 図 7 に示すように，本稿での 実験条件はクラス比を固定したまま各属性を次元とする 属性空間のある部分空間に対応するクラスラベルか変化 するような環境変化に対応する．これは，たとえば組織 を部署と部署内の掛の単位で考えた場合に，組織再編に より掛の単位で別の部署に人員を移動し，移動した掛を 補充するために別の部署に属していた掛を移動すること に対応する .この場合，掛に属する個々の構成員の性質 は変化しないが掛を組織の一部として含む部署の性質が 変化することになる．

\section{$4 \cdot 2$ 実 験 結 果}

データと専門家からの知識獲得，およびデータのみか らの知識獲得に対して光れ攵れ実験した . $X_{c h g 2} \rightarrow X_{c h g 1}$ $\rightarrow X_{\text {org }}$ の変化における実験結果の一例を図 8 , 図 9 に示

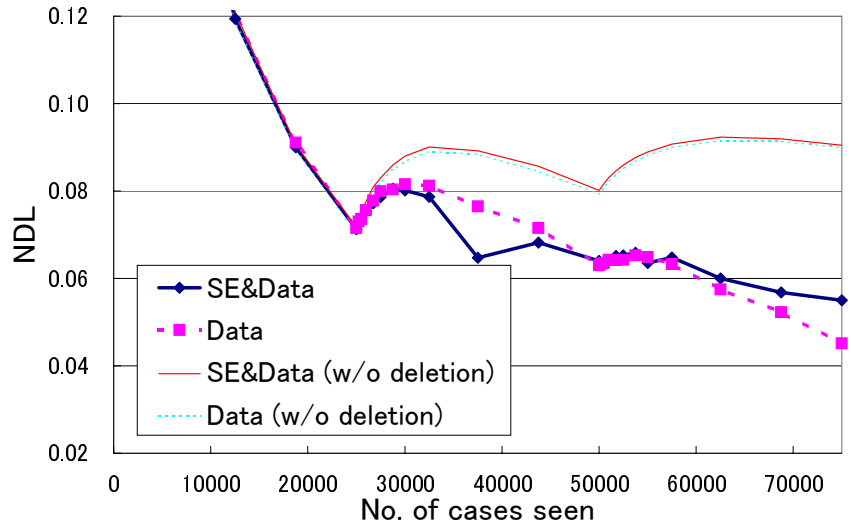

図 9 データセット “PenDigits” に対する NDL の变化 (10 回試 行平均, $X_{c h g 2} \rightarrow X_{c h g 1} \rightarrow X_{\text {org }}$ )

す.図 8 , 図 9 はデータセット “Pen-Digits”におけるエ ラー率, NDL に対する 10 回試行平均の変遷を示す . こ のデータセットでは 25001 事例目と 50001 事例目て環境 か変化し，乥れに伴いエラー率および NDL は一旦上昇 するものの，提案するノード削除機能により RDR シス テムから無効となった知識 (ノード) を削除することに よりエラー率および NDL が咸少していることがわかる． 特に, 環境が静的な間 $(1 \sim 25000$ 事例まで) は知識獲得 に伴い NDL の割合は単調に減少し，環境が変化した時 点でNDL は一旦増加し，変化後にRDR に与えられた 事例に基づいて知識獲得を行うにつれて再び減少すると いう変化が 25001 事例目の前後に現れており，ノード削 除アルゴリズムが適切に機能したことを示唆している .

各環境 $X$ から無作為抽出した事例数を基準として, 変 化の直前までに知識ベースに蓄積された事例数と炎の中 で変化後の環境に対しては有効ではない事例数の比を考 えると, 最初の変化で $10.0 \%, 2$ 番目の変化で $10.5 \% * 2$ となり，削除機能により矛盾した事例が全て削除されると は限らないため後者のほうが環境変化の影響はさらに大 きくなる.このため , 25001 事例目の变化に比して 50001

$* 2$ 各環境 $X$ から無作為抽出した事例数を基準 $(100 \%)$ とする と，理想的には削除機能により $X_{c h g 2}$ で蓄積した事例のうち $X_{c h g 1}$ にとって矛盾した $10 \%$ 事例が削除され，2 番目の変 化の直前では $190 \%$ 分蓄えられている. 兴の中で, $X_{c h g}$ で蓄 積した $10 \%$ と $X_{\text {ch } g 1}$ で蓄積した $10 \%$ は $X_{\text {org }}$ に対して矛盾 する事例となるため，比は $20 \% / 190 \%=10.5 \%$ となる . 
表 3 ノード削除を用いた結果 (枝刈りあり)

\begin{tabular}{|c|c|c|c|c|c|c|c|c|c|}
\hline \multirow[b]{2}{*}{ Data Set } & \multicolumn{4}{|c|}{ データと専門家 } & \multicolumn{4}{|c|}{ データのみ } & \multirow[b]{2}{*}{$\begin{array}{c}\mathrm{C} 4.5 \\
\text { (全事例) }\end{array}$} \\
\hline & 事例数 & NDL & RDR & $\begin{array}{c}\text { C4.5 } \\
\text { (保持事例) }\end{array}$ & 事例数 & NDL & RDR & $\begin{array}{c}\mathrm{C} 4.5 \\
\text { (保持事例) }\end{array}$ & \\
\hline Car & $92.8 \%$ & $16.1 \%$ & $7.7^{*} \%$ & $9.3 \%$ & $92.1 \%$ & $16.2 \%$ & $8.0^{*} \%$ & $9.1 \%$ & $11.6 \%$ \\
\hline Nursery & $91.4 \%$ & $6.2 \%$ & $6.2^{*} \%$ & $5.3 \%$ & $91.5 \%$ & $5.3 \%$ & $5.9 * \%$ & $5.2 \%$ & $8.7 \%$ \\
\hline Mushrooms & $92.7 \%$ & $9.6 \%$ & $6.6 * \%$ & $5.2 \%$ & $91.2 \%$ & $8.6 \%$ & $4.5^{*} \%$ & $4.4 \%$ & $12.2 \%$ \\
\hline Krvkp & $88.1 \%$ & $8.1 \%$ & $5.0^{*} \%$ & $5.2 \%$ & $87.3 \%$ & $9.4 \%$ & $5.4^{*} \%$ & $5.3 \%$ & $10.9 \%$ \\
\hline VotingRecord & $85.1 \%$ & $16.5 \%$ & $8.0 \%$ & $5.2 \%$ & $86.1 \%$ & $19.3 \%$ & $6.7^{*} \%$ & $6.0 \%$ & $7.3 \%$ \\
\hline BreastCancer & $89.9 \%$ & $12.2 \%$ & $4.8 * \%$ & $4.9 \%$ & $89.5 \%$ & $12.0 \%$ & $5.5 * \%$ & $4.5 \%$ & $9.1 \%$ \\
\hline Splice & $87.6 \%$ & $10.1 \%$ & $11.1^{*} \%$ & $10.3 \%$ & $89.1 \%$ & $11.6 \%$ & $12.4^{*} \%$ & $11.4 \%$ & $17.4 \%$ \\
\hline Image & $90.7 \%$ & $6.6 \%$ & $4.9^{*} \%$ & $5.1 \%$ & $89.7 \%$ & $7.0 \%$ & $4.9 * \%$ & $5.1 \%$ & $14.1 \%$ \\
\hline PageBlocks & $84.5 \%$ & $19.3 \%$ & $5.6^{*} \%$ & $6.8 \%$ & $84.9 \%$ & $21.1 \%$ & $6.0^{*} \%$ & $6.0 \%$ & $9.4 \%$ \\
\hline PenDigits & $90.1 \%$ & $5.5 \%$ & $5.9^{*} \%$ & $5.8 \%$ & $90.6 \%$ & $4.5 \%$ & $6.1^{*} \%$ & $5.9 \%$ & $14.2 \%$ \\
\hline Yeast & $60.4 \%$ & $28.4 \%$ & $39.1 \%$ & $34.4 \%$ & $61.8 \%$ & $27.2 \%$ & $38.9 \%$ & $34.1 \%$ & $17.7 \%$ \\
\hline PimaIndians & $44.9 \%$ & $39.5 \%$ & $28.8 \%$ & $24.4 \%$ & $45.5 \%$ & $45.8 \%$ & $29.8 \%$ & $24.6 \%$ & $16.7 \%$ \\
\hline GermanCredit & $63.7 \%$ & $42.3 \%$ & $24.2 \%$ & $23.7 \%$ & $73.8 \%$ & $43.0 \%$ & $21.0 \%$ & $17.9 \%$ & $13.0 \%$ \\
\hline $\mathrm{Cmc}$ & $46.3 \%$ & $49.8 \%$ & $49.0 \%$ & $43.9 \%$ & $33.5 \%$ & $52.9 \%$ & $50.2 \%$ & $48.6 \%$ & $23.3 \%$ \\
\hline AnnThyroid & $87.8 \%$ & $17.2 \%$ & $2.4^{*} \%$ & $3.7 \%$ & $86.3 \%$ & $17.8 \%$ & $3.5^{*} \%$ & $4.4 \%$ & $10.3 \%$ \\
\hline
\end{tabular}

*: RDR のエラー率 < C4.5 (全事例) のエラー率, イタリック体: RDR のエラー率 < C4.5 (保持事例) のエラー率

表 4 ノード削除を用いた結果（枝刈りなし）

\begin{tabular}{|c|c|c|c|c|c|c|c|c|c|}
\hline \multirow[b]{2}{*}{ Data Set } & \multicolumn{4}{|c|}{ データと専門家 } & \multicolumn{4}{|c|}{ データのみ } & \multirow[b]{2}{*}{$\begin{array}{c}\mathrm{C} 4.5 \\
\text { (全事例) }\end{array}$} \\
\hline & 事例数 & NDL & RDR & $\begin{array}{c}\text { C4.5 } \\
\text { (保持事例) }\end{array}$ & 事例数 & NDL & RDR & $\begin{array}{c}\mathrm{C} 4.5 \\
\text { (保持事例) }\end{array}$ & \\
\hline Car & $95.8 \%$ & $23.8 \%$ & $13.0 \%$ & $10.0 \%$ & $95.8 \%$ & $29.9 \%$ & $13.9 \%$ & $10.3 \%$ & $11.6 \%$ \\
\hline Nursery & $95.8 \%$ & $13.2 \%$ & $10.4 \%$ & $7.1 \%$ & $95.2 \%$ & $14.2 \%$ & $9.7 \%$ & $6.5 \%$ & $8.7 \%$ \\
\hline Mushrooms & $93.0 \%$ & $10.8 \%$ & $4.3^{*} \%$ & $5.2 \%$ & $94.6 \%$ & $12.9 \%$ & $4.9^{*} \%$ & $6.9 \%$ & $12.2 \%$ \\
\hline Krvkp & $91.1 \%$ & $11.7 \%$ & $4.8 * \%$ & $5.8 \%$ & $90.7 \%$ & $13.2 \%$ & $6.0 * \%$ & $5.4 \%$ & $10.9 \%$ \\
\hline VotingRecord & $89.6 \%$ & $24.8 \%$ & $9.9 \%$ & $6.2 \%$ & $88.6 \%$ & $25.4 \%$ & $8.2 \%$ & $5.5 \%$ & $7.3 \%$ \\
\hline BreastCancer & $91.2 \%$ & $15.8 \%$ & $5.4^{*} \%$ & $5.4 \%$ & $92.0 \%$ & $16.0 \%$ & $5.4^{*} \%$ & $5.4 \%$ & $9.1 \%$ \\
\hline Splice & $85.4 \%$ & $16.3 \%$ & $12.5^{*} \%$ & $12.8 \%$ & $83.3 \%$ & $25.9 \%$ & $16.7^{*} \%$ & $13.0 \%$ & $17.4 \%$ \\
\hline Image & $95.3 \%$ & $36.1 \%$ & $12.1 * \%$ & $10.3 \%$ & $95.7 \%$ & $38.0 \%$ & $12.7^{*} \%$ & $11.1 \%$ & $14.1 \%$ \\
\hline PageBlocks & $95.4 \%$ & $32.3 \%$ & $8.0^{*} \%$ & $8.2 \%$ & $95.2 \%$ & $34.8 \%$ & $8.2^{*} \%$ & $8.6 \%$ & $9.4 \%$ \\
\hline PenDigits & $95.3 \%$ & $22.3 \%$ & $12.4^{*} \%$ & $11.4 \%$ & $95.4 \%$ & $22.1 \%$ & $12.5^{* \%}$ & $12.0 \%$ & $14.2 \%$ \\
\hline Yeast & $96.6 \%$ & $35.6 \%$ & $18.3 \%$ & $17.5 \%$ & $96.8 \%$ & $36.2 \%$ & $18.9 \%$ & $17.8 \%$ & $17.7 \%$ \\
\hline PimaIndians & $81.4 \%$ & $46.2 \%$ & $16.4^{*} \%$ & $15.9 \%$ & $80.8 \%$ & $45.9 \%$ & $16.3 * \%$ & $16.1 \%$ & $16.7 \%$ \\
\hline GermanCredit & $83.7 \%$ & $45.4 \%$ & $15.7 \%$ & $16.0 \%$ & $83.8 \%$ & $46.6 \%$ & $15.8 \%$ & $15.0 \%$ & $13.0 \%$ \\
\hline $\mathrm{Cmc}$ & $87.9 \%$ & $43.3 \%$ & $26.0 \%$ & $24.6 \%$ & $89.3 \%$ & $44.9 \%$ & $25.5 \%$ & $23.6 \%$ & $23.3 \%$ \\
\hline AnnThyroid & $92.9 \%$ & $30.1 \%$ & $8.0^{*} \%$ & $6.7 \%$ & $93.0 \%$ & $32.8 \%$ & $8.2^{*} \%$ & $6.5 \%$ & $10.3 \%$ \\
\hline
\end{tabular}

*: RDR のエラー率 < C4.5 (全事例) のエラー率, イタリック体: RDR のエラー率 < C4.5 (保持事例) のエラー率

\section{事例目の変化が多少影響が大きかったと考えられる .}

图 8, 図 9 に対応する,$X_{\text {org }} \rightarrow X_{c h g 1} \rightarrow X_{c h g 2}$ の 変化における実験結果の一例を図 10, 図 11 (データセッ 卜“Pen-Digits”におけるエラー率，NDL に対する 10 回試行平均の変遷)に示す .この実験においても，図 8, 图 9 と同樣なノード削除機能の効果が見られた . $X_{c h g}$ $\rightarrow X_{c h g 1} \rightarrow X_{o r g}$ での実験と $X_{o r g} \rightarrow X_{c h g 1} \rightarrow X_{c h g}$ での実験ではほぼ同樣な結果が得られたため，以下では 前者の実験結果に限定して議論する。

15 種類のデータセットに対し, 各試行終了時に構築さ れた RDR システムの評価 ( $X_{\text {org }}^{\text {test }}$ に対するエラー率 $(\%)$ と NDL の 10 回試行における平均值) を表 3 , 表 4 , 表 5 に示す.表 3 , 表 4 は $3 \cdot 1$ 節で提案したノード削除機能 を用いた場合（表 3 は枝刘り機能を用いた場合，表 4 は
枝刈り機能を用いない場合）, 表 5 はノード削除機能を 用いない場合を示す . 各表で “NDL” , "RDR” の列は構 築した RDR システムの正規化した記述長およびエラー 率を示し, “C4.5 (全事例) ”の列は全ての訓練事例に対 して 44.5 を用いて構築した決定木のエラー率を示す. 表 3 , 表 4 の “事例数” の列は RDR システムが各試行終了 時に保持していた事例数の全訓練事例数に対する割合を 示し，“C4.5 (保持事例) ” の列は保持された事例集合に 対して C4.5を用いて構築した決定木のエラー率を示す． また，表 6 に提案した削除機能，枝刚り機能を用いた場 合を各バリェーションと対比した場合の p 值を示す . 表 6 中の $\leq 0.01^{+}$は有意水準 $99 \%$ 以上で削除機能, 枝刈 り機能を用いた場合にエラー率が低い結果であったこと を示す (逆に， $\leq 0.01^{-}$はエラー率が高い結果であった 
表 5 ノード削除を用いない結果

\begin{tabular}{|c|c|c|c|c|c|c|c|c|c|}
\hline \multirow{3}{*}{ Data Set } & \multicolumn{4}{|c|}{ データと専門家 } & \multicolumn{4}{|c|}{ データのみ } & \multirow{3}{*}{$\begin{array}{c}\mathrm{C} 4.5 \\
\text { (全事例) }\end{array}$} \\
\hline & \multicolumn{2}{|c|}{ 枝刈りあり } & \multicolumn{2}{|c|}{ 枝刚りなし } & \multicolumn{2}{|c|}{ 枝刈りあり } & \multicolumn{2}{|c|}{ 枝刈りなし } & \\
\hline & NDL & RDR & NDL & RDR & NDL & RDR & NDL & RDR & \\
\hline Car & $23.5 \%$ & $13.6^{*} \%$ & $27.9 \%$ & $15.3 \%$ & $23.9 \%$ & $13.8^{*} \%$ & $34.0 \%$ & $16.3 \%$ & $11.6 \%$ \\
\hline Nursery & $11.2 \%$ & $11.4^{*} \%$ & $16.8 \%$ & $13.6 \%$ & $11.1 \%$ & $11.4^{*} \%$ & $18.0 \%$ & $13.9 \%$ & $8.7 \%$ \\
\hline Mushrooms & $19.6 \%$ & $11.5^{* \%}$ & $20.2 \%$ & $11.8 \%$ & $19.5 \%$ & $12.2 \%$ & $20.5 \%$ & $11.5 \%$ & $12.2 \%$ \\
\hline Krvkp & $23.1 \%$ & $12.8^{*} \%$ & $24.7 \%$ & $16.0 \%$ & $23.3 \%$ & $13.9^{*} \%$ & $27.0 \%$ & $15.7 \%$ & $10.9 \%$ \\
\hline VotingRecord & $34.2 \%$ & $11.8 \%$ & $38.0 \%$ & $11.7 \%$ & $34.0 \%$ & $12.1 \%$ & $38.6 \%$ & $12.1 \%$ & $7.3 \%$ \\
\hline BreastCancer & $27.8 \%$ & $12.3 \%$ & $30.2 \%$ & $11.8 \%$ & $27.7 \%$ & $11.9 * \%$ & $31.7 \%$ & $12.1 \%$ & $9.1 \%$ \\
\hline Splice & $19.1 \%$ & $17.7^{*} \%$ & $32.3 \%$ & $20.0 \%$ & $19.4 \%$ & $17.4^{*} \%$ & $37.5 \%$ & $21.0 \%$ & $17.4 \%$ \\
\hline Image & $11.4 \%$ & $16.0^{*} \%$ & $40.3 \%$ & $18.0 \%$ & $11.6 \%$ & $16.7^{*} \%$ & $44.0 \%$ & $17.9 \%$ & $14.1 \%$ \\
\hline PageBlocks & $30.4 \%$ & $11.4 \%$ & $40.7 \%$ & $11.2 \%$ & $30.3 \%$ & $11.3 \%$ & $41.7 \%$ & $11.2 \%$ & $9.4 \%$ \\
\hline PenDigits & $9.1 \%$ & $15.7^{*} \%$ & $26.7 \%$ & $17.5 \%$ & $9.0 \%$ & $15.3^{*} \%$ & $26.4 \%$ & $17.6 \%$ & $14.2 \%$ \\
\hline Yeast & $26.4 \%$ & $26.3 \%$ & $38.0 \%$ & $20.7 \%$ & $26.3 \%$ & $25.0 \%$ & $38.6 \%$ & $20.8 \%$ & $17.7 \%$ \\
\hline PimaIndians & $45.8 \%$ & $21.6 \%$ & $53.2 \%$ & $16.4 \%$ & $45.4 \%$ & $18.3 \%$ & $53.1 \%$ & $17.5 \%$ & $16.7 \%$ \\
\hline GermanCredit & $45.4 \%$ & $18.8 \%$ & $53.5 \%$ & $14.0 \%$ & $45.7 \%$ & $18.2 \%$ & $54.6 \%$ & $14.1 \%$ & $13.0 \%$ \\
\hline $\mathrm{Cmc}$ & $49.7 \%$ & $35.5 \%$ & $49.3 \%$ & $27.5 \%$ & $49.3 \%$ & $34.1 \%$ & $50.7 \%$ & $27.1 \%$ & $23.3 \%$ \\
\hline AnnThyroid & $39.1 \%$ & $10.9^{*} \%$ & $42.4 \%$ & $11.5 \%$ & $38.8 \%$ & $10.1^{*} \%$ & $44.5 \%$ & $11.1 \%$ & $10.3 \%$ \\
\hline
\end{tabular}

*: 枝刈り機能を用いたエラー率が低い場合

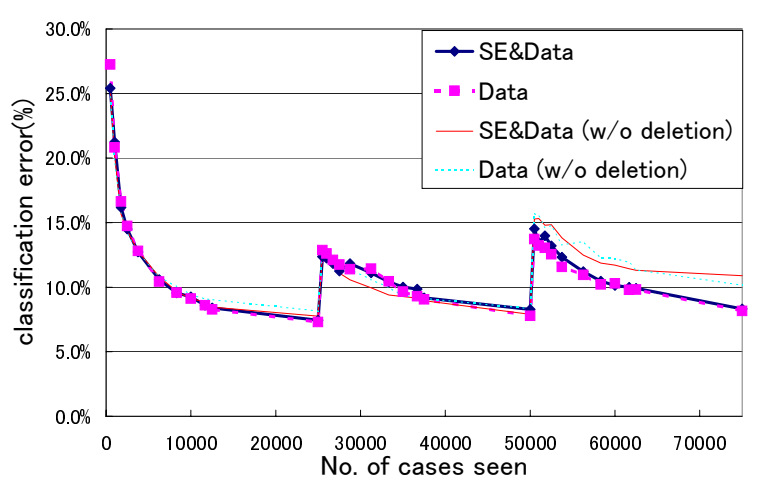

図 10 データセット “PenDigits”に対するエラー率の变化 (10 回 試行平均, $X_{\text {org }} \rightarrow X_{c h g 1} \rightarrow X_{c h g}$ )

ことを示す）.たとえば，表 6 の第 1 列目は，専門家と データからの知識獲得において削除あり，枝刈りありの 場合と削除なし，枝刚りなしの場合を比較した場合の $\mathrm{p}$ 值を示し，データセット Carでは $99 \%$ 有意水準で前者の エラー率が有意に低かったことを示す．

削除機能および枝刈り機能を用いて構筑した RDR シ ステム (表 3 ) と両機能を用いずに構筑した RDR システ 么 (表 5 右側) を比較すると,データと専門家からの知識 獲得およびデータのみからの知識獲得に対して両機能を 用いた場合が 11 データセットに対して有意にエラー率が 低かった．このため，提案した削除機能および枝刈り機 能は環境変化に対して有効に機能したと考えられる.更 に, “C 4.5 (全事例)”と比較しても，データのみから逐 次的に知識獲得して構築した RDR システムのほうが 10 データセットに対してェラー率が有意に低く，RDR シ ステムのほうがエラー率か有意に高くなることはなかっ た 、上記より，環境変化に対して提案手法は有効に機能 するといえる．

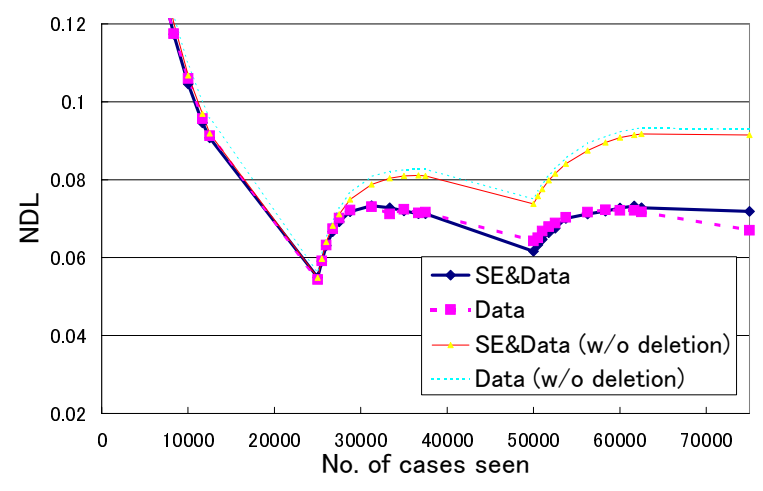

図 11 データセット “PenDigits”に対する NDL の変化 (10 回試 行平均, $X_{o r g} \rightarrow X_{c h g 1} \rightarrow X_{c h g 2}$ )

無効となった知識を保持するノードのみを削除するこ との効果に対して，RDR システムが保持する事例集合 を 4.5 を用いて構築した決定木のエラー率の観点から 評価した . “C 4.5 (保持事例)”と “C 4.5 (全事例)” と 比較すると，前者に対するエラー率が 11 データセットに 対して有意に低かった．このため, 環境変化に伴い無効 となった知識を保持し続けると知識ベースシステムの性 能が劣化するという課題に対し, 提案手法では無効な知 識を保持するノードが削除され，有効な知識を保持する ノードが知識ベースに保存されていることがわかる .

残念ながら 4 データセット ("Yeast", "PimaIndians", “GermanCredit”, “Cmc”) に対してはノード削除機能お よび枝刈り機能を用いた場合にエラー率は悪化した．表 5 でこの 4 データセットはノード削除を行わない場合で も枝刚りを行うと予測精度が悪化しているため, 枝刚り が有効に機能しにくい性質を持つと考えられる．表 3 の “事例数” の列を見ると，他のデータセットと比較して保 持事例の割合か非常に低くなっており，削除機能と枝刈 
表 6 対応のある $\mathrm{t}$ 検定の結果 (片側検定での $\mathrm{p}$ 值)

\begin{tabular}{|c|c|c|c|c|c|c|c|c|}
\hline & \multicolumn{4}{|c|}{$\begin{array}{c}\text { データと専門家 } \\
\text { (削除あり，枝刈りあり) }\end{array}$} & \multicolumn{4}{|c|}{$\begin{array}{c}\text { データのみ } \\
\text { (削除あり, 枝刈りあり) }\end{array}$} \\
\hline & \multicolumn{2}{|c|}{ 枝刈りなし } & \multicolumn{2}{|c|}{$\mathrm{C} 4.5$} & \multicolumn{2}{|c|}{ 枝刈りなし } & \multicolumn{2}{|c|}{$\mathrm{C} 4.5$} \\
\hline & 削除なし & 削除あり & (全事例) & (保持事例) & 削除なし & 削除あり & (全事例) & (保持事例) \\
\hline Car & $\leq 0.01^{+}$ & $\leq 0.01^{+}$ & $\leq 0.01^{+}$ & $\leq 0.01^{+}$ & $\leq 0.01^{+}$ & $\leq 0.01^{+}$ & $\leq 0.01^{+}$ & $0.0844^{+}$ \\
\hline Nursery & $\leq 0.01^{+}$ & $\leq 0.01^{+}$ & $\leq 0.01^{+}$ & $0.0408^{-}$ & $\leq 0.01^{+}$ & $\leq 0.01^{+}$ & $\leq 0.01^{+}$ & $0.1554^{-}$ \\
\hline Mushrooms & $\leq 0.01^{+}$ & $0.0106^{-}$ & $\leq 0.01^{+}$ & $\leq 0.01^{-}$ & $\leq 0.01^{+}$ & $0.3625^{+}$ & $\leq 0.01^{+}$ & $0.4474^{-}$ \\
\hline Krvkp & $\leq 0.01^{+}$ & $0.4207^{-}$ & $\leq 0.01^{+}$ & $0.3638^{+}$ & $\leq 0.01^{+}$ & $0.2346^{+}$ & $\leq 0.01^{+}$ & $0.3880^{-}$ \\
\hline VotingRecord & $0.0338^{+}$ & $0.1285^{+}$ & $0.3346^{-}$ & $\leq 0.01^{-}$ & $\leq 0.01^{+}$ & $0.2160^{+}$ & $0.3250^{+}$ & $0.2790^{-}$ \\
\hline BreastCancer & $\leq 0.01^{+}$ & $0.1630^{+}$ & $\leq 0.01^{+}$ & $0.4615^{+}$ & $\leq 0.01^{+}$ & $0.4450^{-}$ & $\leq 0.01^{+}$ & $0.0955^{-}$ \\
\hline Splice & $\leq 0.01^{+}$ & $0.1408^{+}$ & $\leq 0.01^{+}$ & $0.0519^{-}$ & $\leq 0.01^{+}$ & $0.0109^{+}$ & $\leq 0.01^{+}$ & $0.1203^{-}$ \\
\hline Image & $\leq 0.01^{+}$ & $\leq 0.01^{+}$ & $\leq 0.01^{+}$ & $0.2717^{+}$ & $\leq 0.01^{+}$ & $\leq 0.01^{+}$ & $\leq 0.01^{+}$ & $0.3297^{+}$ \\
\hline PageBlocks & $\leq 0.01^{+}$ & $\leq 0.01^{+}$ & $\leq 0.01^{+}$ & $0.0215^{+}$ & $\leq 0.01^{+}$ & $\leq 0.01^{+}$ & $\leq 0.01^{+}$ & $0.4439^{+}$ \\
\hline PenDigits & $\leq 0.01^{+}$ & $\leq 0.01^{+}$ & $\leq 0.01^{+}$ & $0.4845^{-}$ & $\leq 0.01^{+}$ & $\leq 0.01^{+}$ & $\leq 0.01^{+}$ & $0.2105^{-}$ \\
\hline Yeast & $\leq 0.01^{-}$ & $\leq 0.01^{-}$ & $\leq 0.01^{-}$ & $\leq 0.01^{-}$ & $\leq 0.01^{-}$ & $\leq 0.01^{-}$ & $\leq 0.01^{-}$ & $\leq 0.01^{-}$ \\
\hline Pima & $\leq 0.01^{-}$ & $\leq 0.01^{-}$ & $\leq 0.01^{-}$ & $\leq 0.01^{-}$ & $\leq 0.01^{-}$ & $\leq 0.01^{-}$ & $\leq 0.01^{-}$ & $\leq 0.01^{-}$ \\
\hline GermanCredit & $\leq 0.01^{-}$ & $\leq 0.01^{-}$ & $\leq 0.01^{-}$ & $0.3662^{-}$ & $\leq 0.01^{-}$ & $\leq 0.01^{-}$ & $\leq 0.01^{-}$ & $0.0384^{-}$ \\
\hline $\mathrm{Cmc}$ & $\leq 0.01^{-}$ & $\leq 0.01^{-}$ & $\leq 0.01^{-}$ & $\leq 0.01^{-}$ & $\leq 0.01^{-}$ & $\leq 0.01^{-}$ & $\leq 0.01^{-}$ & $0.1854^{-}$ \\
\hline AnnThyroid & $\leq 0.01^{+}$ & $\leq 0.01^{+}$ & $\leq 0.01^{+}$ & $0.0261^{+}$ & $\leq 0.01^{+}$ & $\leq 0.01^{+}$ & $\leq 0.01^{+}$ & $0.1361^{+}$ \\
\hline
\end{tabular}

${ }^{+}:$削除機能 , 枝刈り機能を用いた場合のエラー率が低い

- : 削除機能，枝刈り機能を用いた場合にエラー率が高い

$\leq 0.01^{+}$: 有意水準 $99 \%$ 以上で削除機能, 枝刈り機能を用いた場合のエラー率が低い

$\leq 0.01^{-}$: 有意水準 $99 \%$ 以上で削除機能，枝刈り機能を用いた場合のエラー率が高い

り機能を組み合わせて用いた場合に枝刈りによる二分木 の再編が過乘なノード削除を誘引したと考えられる．表 3 と表 4 を比較すると，この 4 データセットに対しては 枝刈りを用いずにノード削除を行った場合に保持事例の 割合か増加し，エラー率も減少している。また，表 4 で “RDR”と“C4.5 (全事例) ”を比較すると，枝刈りを用 いずにノード削除のみを行った場合でもエラー率は有意 に低くなった · 上記の結果より，データセットによって は削除機能と枝刈り機能を組み合わせると性能（エラー 率) が悪化する場合もあるが，弚の場合は枝刈りを行わ ないことで対処できると考えられる。

同じ保持事例に対してであっても，逐次的に知識獲得 を行う RDR 法のほうがバッチ処理的な C4.5 よりも低い エラー率を示したデータセットがあることは注目に值す る.たとえば，表 3 ではデータと専門家からの知識獲得 に対しては RDR システムのほうが 5 データセットに対 してエラー率が低く, データのみからの知識獲得に対し ては 2 データセットに対してエラー率が低かった .また， エラー率と NDL がほぼ同期しており，NDL が低い場合 にはエラー率も低くなっている．上記の結果より，NDL に基づいて RDR システムを構築することは環境変化へ の対応を実現するうえで有効であるといえる .

表 5 で枝刚り機能を用いた場合と用いない場合の RDR のエラー率を比較すると，データと専門家からの知識獲得 とデータのみからの知識獲得でともに*をつけた 8 デー タセットで枝刈り機能を用いた場合にエラー率が低かっ た．また，表 6 で削除機能および枝刈り機能を用いた場 合と削除機能のみを用いた場合を比較すると，データと
専門家からの知識獲得とデータのみからの知識獲得でと もに 6 データセット (表 6 で $\left.\leq^{+}\right)$に対して枝刚り機能 も併用したほうが有意にエラー率が低かった . 汎化によ る予測精度の向上が枝刈りの目的であるが , 環境変化へ の対応に関しても有効に機能するといえる．

\section{5. おわりに}

本稿では環境変化の一例として同じ属性-属性値の組合 せを持つ事例に対するクラスラベルの変化を考え, 以前 正しいと判断され蓄積された知識か漬境変化に伴って有 効性を失うことに対応するために，知識削除機能と知識 沉化機能を導入して RDR 法の知識ベースシステムを構 築する手法を提案した. [和田 01b] で提案した最小記述 長原理を用いて専門家からの知識獲得とデータからの帰 納学習手法を RDR 法に統合化する手法を拡張し，知識 の追加, 削除, 汎化に伴う RDR 法の知識ベースシステ ムの再編を正規化した記述長の最小化という規範で実現 できることを示した . 15 種類のデータセットに対する人 エデータを用いた実験から，提案する両機能を用いた場 合に知識ベースシステムの性能が向上することを確認し た .また，対象データの性質によっては知識汎化機能を 用いると逆に性能が悪化することがあるという課題も明 らかになった .

今後の課題として以下の 3 点に取り組む．

1) RDR 法の二分木を再編すると，ノード削除前後で 知識の整合性は維持されるものの，削除後の二分木が $\mathrm{NO}$ 枝に偏りがちになるという課題がある (関数 delete_node 
を用いた二分木の再編） . もともと RDR 法の二分木は 知識獲得の過程でも例外知識に対応するノードの追加に より $\mathrm{NO}$ 枝に偏る傾向があるため , ノードの削除により 更に木構造が偏ってしまうことを防ぐようなノード削除 方法を検討する 。

2) 1)の課題に対処するため，枝刈り対象候補ノードを ヒューリスティックな方法で選択していることに対し，枝 刚りが不必要なノードを記述長の観点から理論的に検討 し，必要十分なノードだけを候補とする方法を検討する． 3) 全体の記述長を計算する際に用いる重みを，経験的 に知識獲得およびノード削除では 0.3 , 枝刈りでは 0.7 と 設定している.しかし，真に適切な符号化方法を採用す ればこの重みは必要ないはずである．提案手法の効果が 見られたデータセットの特性と見られなかったデータセッ 卜の特性の違いをもとに符号化の方法と重みの関係をよ り深く検討し，重みに鈍感な（あるいは重みを不要とす る) 符号化方法を導入することで, データセットの特性 の違いにも頑強な提案手法を実現する .

\section{謝 辞}

本研究の一部は文部科学省科研費特定領域研究「情報洪 水時代におけるアクティブマイニングの実現」(No.13131101, No.13131206) の補助による.最後に，有益なご指摘を 賜りました査読者の方々に深く謝意を表します。

\section{$\diamond$ 参 考 文 献 $\diamond$}

[Blake 98] Blake, C. and Merz, C.: UCI Repository of machine learning databases (1998), http :// www.ics.uci.edu / $\sim$ mlearn / MLRepository.html

[Compton 89] Compton, P., Horn, K., Quinlan, J., and Lazarus, L.: Maintaining an Expert System, in Quinlan, J. ed., Application of Expert Systems, pp. 366-385, Addison Wesley (1989)

[Compton 95] Compton, P., Preston, P., and Kang, B.: The Use of Simulated Experts in Evaluating Knowledge Acquisition, in Proc. of the 9th Knowledge Acquisition for Knowledge Based Systems Workshop (1995)

[Morik 93] Morik, K., Wrobel, S., Kietz, J., and Emde, W. eds.: Knowledge Acquisition and Machine Learning: Theory, Methods, and Applications, Academic Press (1993)

[Quinlan 93] Quinlan, J. ed.: C4.5: Programs for Machine Learning, Morgan Kaufmann (1993)

[Rissanen 78] Rissanen, J.: Modeling by Shortest Data Description, Automatica, pp. 465-471 (1978)

[和田 00] 和田 卓也, 堀内 匡, 元田 浩, 熟尾 隆 : Ripple Down Rules 法における知識獲得の特性評価に基づくデフォルト知識の 決定規範, 人工知能学会誌, Vol. 15, No. 1, pp. 177-186 (2000)

[Wada 01a] Wada, T., Motoda, H., and Washio, T.: Knowledge Acquisition from Both Human Expert and Data, in Proc. of the Fifth Pacific-Asia Conference on Knowledge Discovery and Data Mining (PAKDD2001), pp. 550-561, HongKong China (2001), Springer-Verlag

[和田 01b] 和田 卓也, 元田 浩, 熟尾隆 : 最小記述長原理を用い た帰納学習の Ripple Down Rules 法への統合化, 人工知能学会 論文誌, Vol. 16, No. 2, pp. 268-278 (2001)

[Wrobel 94] Wrobel, S. ed.: Concept Formation and Knowledge Revision, Kluwer Academic Publishers (1994)
〔担当委員 : 津本周作〕

2003 年 10 月 23 日 受理

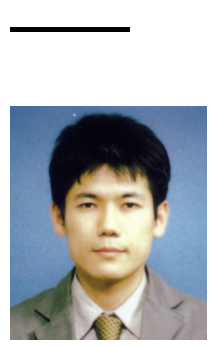

者 紹 介

吉田＼cjkstart哲也(正会員)

1991 年東京大学工学部航空工学科卒業. 1992 年から 1993 年にかけてエジンバラ大学大学院留学. 1994 年から 1995 年にかけてカリフォルニア大学バークレー校交換留 学. 1997 年東京大学大学院博士課程修了. 工学博士. 同 年, 大阪大学大学院基礎工学研究科助手. 現在, 北海道大 学大学院情報科学研究科助教授. 主に機械学習, 知識獲得 データマイニングなどの研究に興味を持つ . 人工知能学会 情報処理学会, ヒューマンインタフェース学会, 各会員.

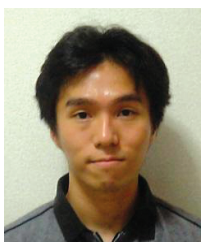

和田 卓也(正会員)

1998 年大阪大学工学部通信工学科卒業. 2001 年同大学 院博士後期課程修了。博士 (工学) . 2001 年から 2002 年にかけて日本学術振興会, 特別研究員. 2002 年日本才 ルガノン (株) 入社.バイオインフォマティクスの研究に 従事. 2003 年から藤沢薬品工業（株）に勤務.配列デー 夕解析, 実験デー夕解析, 文献マイニングなどを介して 創薬研究に従事 . 人間からの知識獲得と产の利用法に関す る研究に興味を持つ. 人工知能学会会員

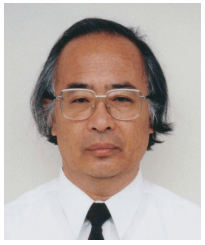

\section{元田 浩(正会員)}

1965 年東京大学工学部原子力工学科卒業. 1967 年同大 学院原子力工学専攻修士課程終了.同年，日立製作所に入 社. 同社中央研究所, 原子力研究所, エネルギー研究所, 基 礎研究所を経て平成 7 年退社. 現在, 大阪大学産業科学究 所教授 (知能システム科学研究部門, 高次推論研究分野) 。 原子カシステムの設計, 運用, 制御に関する研究, 診断型 エキスパート・システムの研究を経て, 現在は人工知能の 基礎研究, とくに機械学習, 知識獲得, 知識発見, データ マイニングなどの研究に従事.工学博士 . 日本ソフトウェア科学会理事 , 人工知 能学会理事, 同編集委員会委員, 日本認知科学会編集委員会委員, Knowledge Acquisition (Academic Press) 編集委員, IEEE Expert 編集委員を歷任。 Advanced Engineering Informatics (Elsevier Applied Science) 編集 委員, International Journal of Human-Computer Studies (Academic Press) 編集委員, Knowledge and Information Systems: An International Journal (Springer-Verlag) 編集委員 . Intelligent Data Analysis: An International Journsal(IOS Press) 編集委員. 1975 年日本原子力学 会将励賞, 1977,1984 年日本原子力学会論文賞, $1991,1994,2002$ 年人工 知能学会論文賞受賞. 2001 年人工知能学会業績賞受賞, 人工知能学会, 情報処理 学会, 日本ソフトウエア科学会, 日本認知科学会, AAAI, IEEE Computer Society, 各会員.

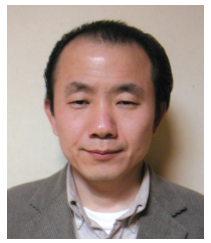

\section{鷲尾隆(正会員)}

1960 年生. 1983 年東北大学工学部原子核工学科卒業 1988 年東北大学大学院原子核工学専攻博士課程修了. 工 学博士.1988 年から 1990 年にかけてマセチューセッツ 工科大学原子炉研究所客員研究員. 1990 年 (株) 三菱総 合研究所入社. 1996 年退社. 現在, 大阪大学産業科学研究 所助教授 (知能システム科学研究部門) 原子カシステムの 異常診断手法に関する研究, 定性推論に関する研究を経て 現在は人工知能の基礎研究, 特に科学的知識発見, データ マイニングなどの研究に従事. 1988 年 2 月計測自動制御学会学術奖励賞受賞 1995 年 8 月人工知能学会全国大会優秀論文賞受賞, 他 2 件. 1996 年 3 月日本 原子力学会論文賞受賞, 1996 年 12 月人工知能学会研究奨励賞受賞, 他 1 件.著 書に "Expert Systems Applications within the Nuclear Industry", American Nuclear Society, 知能工学概論」 : 第2 章エージェント (共著, 廣 田 薰 編, 昭晃堂) など. AAAI, 人工知能学会, 計測自動制御学会, 情報処 理学会, 日本ファジイ学会, 各会員 